\title{
THE ANTINOMIES OF RACIAL CHANGE
}

\author{
Lawrence D. Bobo \\ Department of Sociology and of African and African American Studies, \\ Harvard University
}

Discussions of complexity and change in matters of ethnoracial relations often obscure as much as they describe and illuminate. In part, this is so because such distinctions, racial ones in particular, are not now nor have they ever been fixed, static, and natural categories. They are instead malleable social constructions. In part, it is so because expressly ideological projects are typically embedded within the claims scholars make about ethnoracial patterns. Consider the assertion that hybridity and mixture are ending the relevance of race, or that global population flows, massive immigration, and "super-diversity" will, likewise, render notions of race passé. The trouble here is that the crossing of socially imposed lines of race and ethnicity, as well as contact among diverse peoples, has long characterized the human experience.

Absent an explicit theory of the dynamics of ethnoracial relations, claims about the current configurations of groups and likely trends have an untethered quality; antinomies abound. Thus, a cursory scan across the social sciences leaves us noting that in the United States, our project should be to reach beyond identity (Brubaker and Cooper, 2000) and beyond race (Sniderman and Carmines, 1997) while for others colorblindness is racism (Bonilla-Silva 2006) and the neoliberal solution has ushered in Laissez Faire racism to replace Jim Crow racism (Bobo et al., 1997); that specifically anti-Black racial discrimination has waned to the point of being a "secondorder" consideration for some (Heckman 2011), though it ranks as a systemic condition spanning most domains of life, and therefore has an emergent ontological standing best characterized as uber-discrimination for others (Reskin 2012); and that immigration of Latinos has destabilized old Black-White dichotomies to the point that the United States is now on a postracial trajectory (Hollinger 2011) though the Latino experience is an increasingly racialized one itself (Massey 2006; Telles and Ortiz, 2008). One scholar's blurred boundaries (Alba 2005; Wimmer 2008) are evidence of the re-articulation and re-forging of durable group boundaries to others (Bobo 2012; Fox and Guglielmo, 2012; Gans 2012).

The antinomies of race thus play out in both scholarship and real, lived social experience. This issue of the Du Bois Review: Social Science Research on Race tackles 
these antinomies with a powerful set of discussions, essays, new empirical research, and reviews. As perhaps befits the deep perplexity of ethnoracial division in our times, this issue features three entries that pivot centrally off the contributions of the über-race scholar, this journal's namesake, W. E. B. Du Bois. In our "State of the Discourse" section, eminent scholar and public intellectual Cornel West discusses Du Bois as a "figure of our times." His remarks range over Du Bois's penetrating and lasting scholarly contributions, his transformational vision, his growth and change over the long span of his career, as well as the limitations we can now see in his oeuvre. Importantly, the interview is a critical reminder of how the most lasting research on race strives not just for scientific accuracy but is also animated by the zealous pursuit of greater knowledge (not narrow academic careerism) and realization of human fulfillment.

Two other major pieces on Du Bois address, in one case, the start of Du Bois's scholarly career and, in the other case, the last years of his life as a global public figure. Sociologist Marcus Anthony Hunter revisits Du Bois's The Philadelphia Negro ([1899] 2007). His purpose is to show that in this pioneering sociological work Du Bois provided not merely a portrait of the seventh ward of Philadelphia in the late nineteenth century, but a template for urban sociology. Accordingly, Du Bois's master work showed how historical paths of development, racial identities and attitudes, and configurations of social space, combined to explain the conundrum of socioeconomic marginality for Blacks amid larger patterns of industrialization and a group's active search for freedom and opportunity. Historian Yunxiang Gao offers an engaging reminder of the international reach of Du Bois as thinker, scholar, and public figure. She examines in detail W. E. B. and Shirley Graham Du Bois's visits to China, meetings with Premier Zhou Enlai, and Mao Zedong. Her work offers a vivid illustration of Du Bois's engagement with colonialism, imperialism, White supremacy, and racism as truly global problems, not merely an American Black-White problem. It also raises to prominence both the harassment by the U.S. government Du Bois faced in his later years and a complex of issues raised by Du Bois's embrace of Soviet and Chinese communism.

Three articles focus centrally on internal processes within the contemporary African American community. Each provides analysis of particular domains of life but all point to the manifold ways that race and racial inequality continue to shape the identities and life experiences of African Americans. Thus, whether refracted through the lens of regional mobility, of rape, sexual assault and gender, or of elite class status and matters of philanthropic giving, these new empirical investigations highlight the modern dynamic of race. Sociologist Sabrina Pendergrass examines the beliefs and experiences of Blacks who are part of the recent reverse migration stream from North to South. In particular, she conducts in-depth interviews with 127 non-southern-born Blacks who moved to Charlotte, North Carolina. Her work identifies themes regarding differences between North and South in the nature of White prejudice, Black economic opportunity, the symbols and actual risks of racial domination and violence, as well as paternalistic interactions with Whites that shape Blacks' perceptions.

Sociologist C. Shawn McGuffey examines how female African American rape victims seek to cope with and make sense of intraracial sexual violence. His interviews with 111 rape survivors show how race, culture, and racism frame the challenges these women faced and the understandings they forged. In particular he highlights how an intersectional approach, informed by a structural symbolic interactionist theoretical model, reveal themes of Black promiscuity, the Black superwoman, and the cultural protector in the appraisals made by the Black women victims of sexual violence. In so doing, he illustrates the continuing operation of tropes of the Black Jezebel (promiscuity) and the Black mammy (asexual strength) 
images, as well as the on-going force of the politics of respectability in Black America (cultural protector).

Sociologist Jane Jones considers the philanthropic activity of highly successful African Americans. She interviews twenty African Americans in New York who might be regarded as exemplars of the most successful segment of the Talented Tenth, a sort of ultra-elite. Jones examines the views, the identities, and the giving patterns of this Black elite as reflective of a deep sociological ambivalence. On the one hand, these individuals are highly successful and circulating in the upper circles of the New York cultural and financial scenes as exemplified by, for instance, membership on the Lincoln Center Board or that of the New York Public Library. She suggests that these "donors attempt to allay their ambivalence by developing strategies for both distance and intimacy with charitable causes and organizations that are racialized as Black." These individuals were often critical of Black non-profit organizations and their management. Yet, they would seek to support Black causes within mainstream institutions. For many of her respondents it was important to resist a sense of special obligation to distinctly Black organizations while at the same moment still holding a Black identity and seeing some value in advancing aspects of a Black agenda.

Two pieces examine race from the vantage point of the Asian American community. One pursues what might be regarded as a meso-level focus, examining the activities of community-based organizations (CBO), and the other takes a more micro-level focus on intergroup attitudes and ideologies. Sociologists Dina Okamoto and Melanie Jones Gast explore the strategies of Asian community-based organizations in the cities of San Francisco and Oakland, California. Their work identifies two very different types of engagement with the ethnoracial diversity of the region. All of the organizations among the thirty-seven Asian community CBOs where they conducted research could be viewed as involved in a degree of cross-racial work, namely "the organizational practices, programs, and partnerships to include, serve, or work with people, organizations, or communities representing a different racial background." Most of the CBOs, however, engaged in what they term "racial accommodation activities." They might incorporate individuals or work with groups from other ethnoracial groups, but preserve a distinctly Asian community identity and mission. Some of the groups, however, moved in the direction of full racial inclusion, conceiving of their membership and mission as spanning multiple ethnoracial groups.

Sociologist Frank Samson takes a sociopolitical psychology approach to the debates over criteria for college admission. He frames his research, involving surveybased experiments in California, as a test of White Americans' commitments to merit-based criteria of college admission in the light of the growing proportion of Asians at elite institutions of higher learning. His research suggests that commitment to particular criteria of merit-based admission has more contextual and groupinterested ideological grounding than is typically acknowledged in most political rhetoric on the subject. When focused on different groups (i.e., Asians vs. African Americans) and contextual factors (i.e., cues of disproportionate Asian enrollments), the degree of commitment to certain criteria of admission varies.

Two articles examine issues of distinct but not exclusive concern to the Latino population. One takes up the health status of minority populations and the other considers debate and potential policy change in the United States (and elsewhere) to birthright citizenship. Both showcase the obdurate power of race and processes of racialization. Public health and policy analysts Brenda Henry-Sanchez and Arline Geronimus examine patterns of infant mortality among U.S. Latinos. They formulate a segmented racialization account of difference experiences among Latino groups. 


\section{Lawrence D. Bobo}

Specifically they refer to "the differential manner in which Mexicans, Cubans, and Puerto Ricans may be racialized within the United States. . . Cubans were structurally racialized as White, Mexicans as non-White or other, and Puerto Ricans as Black, and that these initial modes of racialization have had long-lasting consequences for health, contributing to patterns of birth outcome seen among groups." Using National Center for Health Statics data on infant mortality levels and types for two eras, they show how this racialization plays out in changing levels and causes of infant death.

Political theorist Annie Menzel uses philosopher Charles Mills' (1997) provocative argument about 'The Racial Contract' to frame an analysis of the political mobilization against birthright citizenship in the United States and other western nations. The purpose here, much like Mills' original effort, is to sketch out the basic scaffolding of an approach or argument rather than to meticulously parse the current dynamics. Nonetheless, she is able to show the profound historically and contemporaneously racialized character of this debate.

The articles by Henry-Sanchez and Geronimus and by Menzel can be read as illustrations of processes of boundary articulation and maintenance, a critical subject in sociology of culture work on race. Sociologist Chinyere Osuji takes up this matter with a focus on the experience of boundary policing encountered by interracial couples in Brazil and in the United States. Specially, she interviews Black-White couples in Rio de Janeiro and in Los Angeles in order to map their perceptions of how frequently and from whom they most often encounter hostility. In both settings couples perceived some degree of stigmatization or boundary policing. This experience was conditioned by the background of the U.S. couple (Black male/White female versus White male/Black female pairings) and the race and gender of other social actors in the United States. She reports that while female partners of Black males reported more sanctioning behavior from Black females, in Brazil, overall reports of sanctioning behavior were lower, but occurred with greater frequency, especially toward the Black female partners of White males when in high-status and Whiter sections of Rio.

Two book review essays take up the matter of the antinomies of race as well. Tiffany Joseph reviews two major new books on how the growing presence of Latinos is remaking racial thinking in the United States. The works she considers, and her take on them, point to elaboration of racial boundaries and processes of racialization, not to the undoing of race categories and identities. Amanda Lewis's review examines two recent books on the "acting white hypothesis;" namely, the suggestion that much of the African American-White achievement gap can be traced to a culture of in-group loyalty and rejection of commitment to schooling and achievement seen as arenas reserved for White Americans. Both books, one mainly quantitative and the other mainly qualitative, reject the core of the acting White hypothesis. Lewis, like many others, raises the question of why this hypothesis has such traction since numerous efforts to find support for it fail to do so, rendering it the "theory that won't die." The survival, indeed the broad popular resonance of the acting White hypothesis, she takes as one further sign of the power of racism and White supremacy in our culture and institutions.

Were Du Bois alive to survey the intellectual landscape today I do not think he would be surprised by the, if you will, post-modern antinomies of race. For regular readers of the empirical research and theoretical ideas published in the $D u$ Bois Review, from this issue and those of the past, it is probably not too large a speculation to suggest that $\mathrm{Du}$ Bois would likely be a skeptic of any logic holding that growing complexity foretells the end of colorism, race, and racial division. Such a transfor- 
mative project is a worthy ambition. But hope should not be allowed to displace a clear-eyed read on history, an honest fix on the terms and conditions of the present, and an understanding of the deep structures of racial inequality.

\section{REFERENCES}

Alba, Richard D. (2005). Bright vs. Blurred Boundaries: Second-Generation Assimilation and Exclusion in France, Germany, and the United States. Ethnic and Racial Studies, 28: 20-49.

Bobo, Lawrence D. (2012). An American Conundrum: Race, Sociology, and the African American Road to Citizenship. In Henry Louis Gates, Jr. et al. (Eds.), The Oxford Handbook of African American Citizenship, 1865-Present, pp. 19-70. New York: Oxford University Press.

Bobo, Lawrence D., James R. Kluegel, and Ryan A. Smith (1997). Laissez-Faire Racism: The Crystallization of a Kinder, Gentler Antiblack Ideology. In Steven Tuch and Jack K. Martin (Eds.), Racial Attitudes in the 1990s: Continuity and Change, pp. 15-44. Greenwood, CT: Praeger.

Bonilla-Silva, Eduardo (2006). Racism without Racists: Color-blind Racism and the Persistence of Racial Inequality in the United States. Lanham, MD: Rowan and Littlefield.

Brubaker, Rogers and Frederick Cooper (2000). Beyond Identity. Theory and Society, 29: 1-47.

Du Bois, W. E. B. ([1899] 2007). The Philadelphia Negro: A Social Study. New York: Oxford University Press.

Fox, Cybelle and Thomas Guglielmo (2012). Defining America's Racial Boundaries: Blacks, Mexicans, and European Immigrants, 1898-1945. American fournal of Sociology, 118(2): $327-379$.

Gans, Herbert J. (2012). 'Whitening' and the Changing American Racial Hierarchy. The Du Bois Review: Social Science Research on Race, 9(2): 267-279.

Heckman, James (2011). The American Family in Black \& White: A Post-Racial Strategy for Improving Skills to Promote Equality. Daedalus, 140(2): 70-89.

Hollinger, David (2011). The Concept of Post-Racial: How Its Easy Dismissal Obscures Important Questions. Daedalus, 140(1): 174-182.

Massey, Douglas S. (2006). Categorically Unequal: The American Stratification System. New York: Russell Sage Foundation.

Mills, Charles (1997). The Racial Contract. Ithaca, NY: Cornell University Press.

Reskin, Barbara (2012). The Race Discrimination System. Annual Review of Sociology, 38: $17-35$.

Sniderman, Paul M. and Edward Carmines (1997). Reaching Beyond Race. Cambridge, MA: Harvard University Press.

Telles, Edward E. and Vilma Ortiz (2008). Generations of Exclusion: Mexican Americans, Assimilation, and Race. New York: Russell Sage Foundation.

Wimmer, Andreas (2008). The Making and Unmaking of Ethnic Boundaries: A Multilevel Process Theory. American Fournal of Sociology, 113(4): 970-1022. 